\title{
Investigating a Suitable Empirical Model and Performing Regional Analysis for the Suspended Sediment Load Prediction in Major Rivers of the Aegean Region, Turkey
}

\author{
Asli Ulke ${ }^{1} \cdot$ Gokmen Tayfur $^{2} \cdot$ Sevinc Ozkul $^{3}$
}

Received: 12 February 2016 / Accepted: 11 May 2016/

Published online: 27 May 2016

(C) Springer Science+Business Media Dordrecht 2016

\begin{abstract}
This study investigates the appropriateness of four major empirical methods [Lane and Kalinske, Einstein, Brooks, Chang-Simons_-Richardson] for predicting suspended sediment loads (SSLs) in three major rivers in the Aegean Region, Turkey. The measured data from 1975 to 2005 were used to test performance of the models. It was found that Brooks method was more appropriate, among the others, for predicting suspended sediment loads from each river. The prediction results of Brooks method were further improved by the use of genetic algorithm (GA_Brooks) optimizing a fitting parameter and showing a comparable performance to those of artificial neural networks (ANNs) and neuro-fuzzy (ANFIS) models for the same rivers. GA_Brooks, ANNs, and ANFIS models can be used for predicting loads at a regional scale. The sensitivity analysis results revealed that suspended and bed material particle diameters affect suspended sediment loads significantly.
\end{abstract}

Keywords Suspended sediment · Aegean region · Empirical methods · Brooks method · Regional analysis

\section{Introduction}

Transported sediments in the rivers, has become one of our water problems, as a result of natural erosion. There is a requirement to know the amount of sediment carried by rivers in the design of water storage facilities and other water control structures which will be built on the streams. For the accumulation of sediment volume transported with streams

Asli Ulke

asli.ulke@omu.edu.tr

Department of Civil Engineering, Engineering Faculty, Ondokuz Mayis University, Samsun, Turkey

2 Department of Civil Engineering, Engineering Faculty, Izmir Institute of Technology, Urla, Izmir, Turkey

3 Department of Civil Engineering, Engineering Faculty, Dokuz Eylul University, Izmir, Turkey 
in the reservoirs, a passive reservoir volume is designed which is called dead volume. Especially in the water storage facilities such as dams, accumulating large amounts of sediment than dead volume, reduces the reservoir capacity and leads to clogging of water intake structures over time. This reservoir capacity reduction caused to reduce the useful life of a dam. It cannot function as a reservoir by time. Another current problem about sediment transport is the pollution of a river. This issue has gained importance in recent years due to environmental impact. Industrial and agricultural residue that emptied into rivers is caused the solids in the bottom contaminated with toxic.

This pollution brings out the water quality problems, especially for streams used for irrigation and water intake structures (Nagy et al. 2002). Suspended sediment load plays an important role especially in transport of inorganic pollutants such as heavy metals in the stream. Studies carried out about the subject shows that suspended sediment particles absorb a large amount of pollutants and bio-cells and transported them to the downstream region (Gray and Fisk 1992; Horowitz 1997, Woitke et al. 2003).

An accurate sediment estimation has always been a major challenge for water resources engineers because of significant spatial and temporal variation in sediment concentration and flow rate. In most streams, a great part of the total load consists of suspended sediment which is also highly important in environmental quality assessment (Yang 1996; Simons and Senturk 1992; Julien 2002)

Suspended sediment load (SSL) can be determined by means of several methods, such as direct measurements (EIE 2006) at sediment gauging stations, the sediment rating curve (EIE 2006; Ulke et al. 2009; Lee and Lee 2010), the regression methods (Kisi et al. 2008), the artificial intelligence methods like artificial neural network (Tayfur and Guldal 2006; Alp and Cığızoğlu 2007), wavelet based artificial intelligence models (Partal and Cigizoglu 2008; Rajaee 2011; Nourani and Andalib 2015), support vector machine models (Kisi 2012; Lafdani et al. 2013; Nourani et al. 2016) gene expressions and genetic programming models (Aytek and Kisi 2008; Kisi and Shiri 2012; Guven and Kisi 2011, Kisi et al. 2012), and finally the empirical methods (Picouet et al. 2001; Camenen and Larson 2008).

Although the direct measurement is the most reliable method, it is very expensive, time consuming and, in many instances, problematic for inaccessible sections, especially during floods. Also, faulty results may occur due to the sampling procedure (Olive and Rieger 1988; Ozturk et al. 2001). Hence, the measurements of suspended sediment load are carried out in longer periods compared with precipitation and flow. Since measuring the precipitation and the flow discharge are relatively cheap and easy, there are more rain and flow gauging stations than SSL gauging stations in Turkey, and the Aegean region is no exception. In this region, located on the western part of Turkey (Fig. 1), presently there are 26 rain gauging stations (DMI 2010) operated by the State Meteorological Service (DMI) and 27 flow rate gauging stations (EIE 2010), but there are only 6 sediment gauging stations, operated by the General Directorate of Electrical Power Resources Survey and Development Administration (EIE). Once or twice a month, the regional EIE offices send technicians to the stations to carry out the suspended sediment measurements (EIE Aydin Office, personal communications).

SSL of a stream in Turkey is generally determined by using the sediment rating curve (SRC) method (EIE 2006). However, since this method is a regression-based, it has accuracy limitations. Ulke et al. (2009) showed that the artificial intelligence methods had superiority over the SRC method for the Gediz River. The soft computing methods, such as ANNs, are not easily welcome by practitioner engineers due to two main 


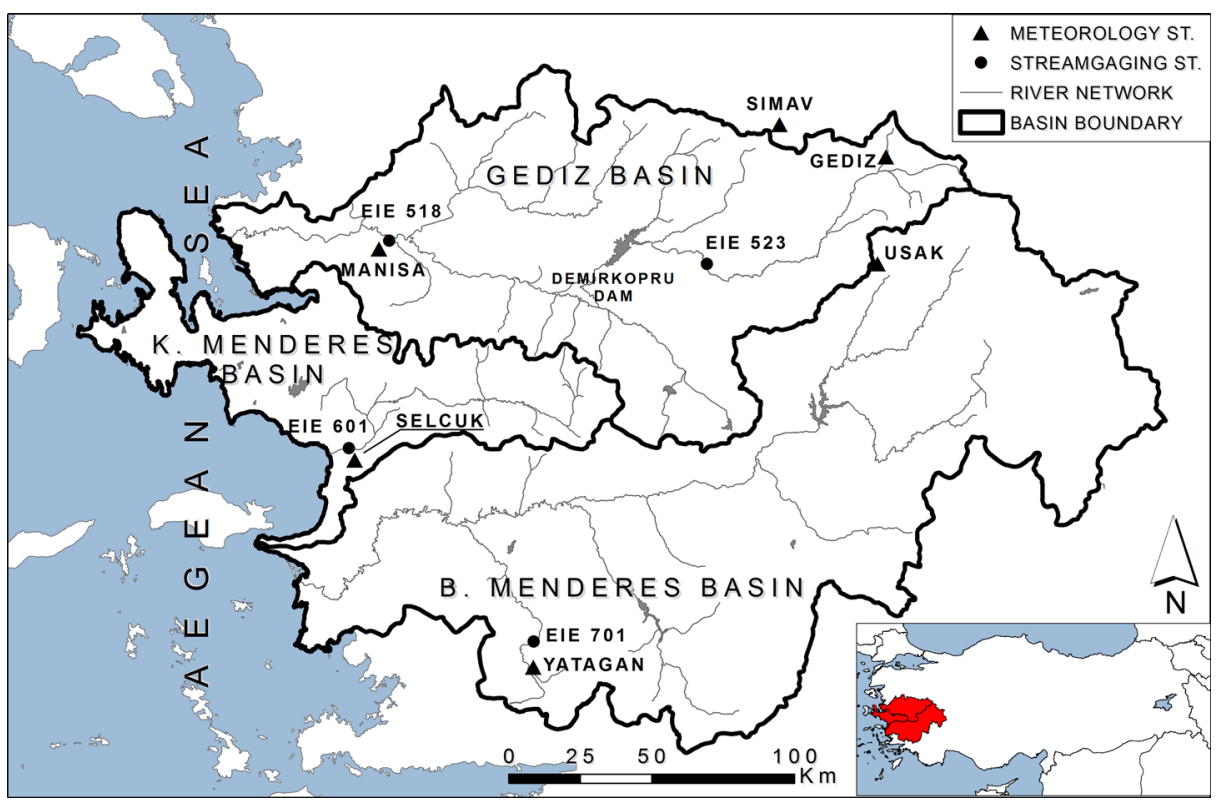

Fig. 1 Location of sediment stations on Gediz, B. Menderes and K. Menderes Basins

reasons: (1) they are data-driven black box models, and (2) traditional engineers are not ready for a change.

For a comprehensive and reliable SSL estimation, the physics-based models, which are based on governing equations of conservation of mass for water and sediment and momentum for flow, can be employed (Singh and Woolhiser 2002; Wu 2004; Wu et al. 2004; Tayfur and Singh 2006; Tayfur and Singh 2007; Singh and Tayfur 2008).

These equations need to be solved numerically and require, for accurate predictions, substantial detail field data (Kavvas et al. 2006; Rojas et al. 2008), which is rarely available, especially in river sections where there is no even a gauging station, such as the Aegean Region. In developing countries, where lack of field data is quite common, such as Turkey the empirical models may be utilized.

Empirical formulas can predict the rate of sediment transport in a field with a margin of error since these formulas are derived from laboratory experiments (Yang 1996; Yang et al. 2009). Although several researchers have applied some of the empirical models in a field situation (Girma and Horlacher 2004; Ladewig 2006), there is no study, to the best knowledge of the authors, on the application of these methods for the major rivers of the Gediz, the Buyuk Menderes, and the Kucuk Menderes (Fig. 1) in the Aegean Region, Turkey.

In this study, four major empirical approaches [Lane and Kalinske, Einstein, Brooks, Chang-Simons - Richardson] were applied for the suspended sediment load predictions in the Gediz, Kucuk Menderes, and Buyuk Menderes Rivers, which are the main water resources of the Aegean region. There are presently 27 major dams and 27 small size water detention reservoirs in operation and 13 dams and 2 detention reservoirs under the construction of these major rivers (DSI 2010). Most of these hydraulic structures are to provide mainly irrigation water for the fertile region and the sediment is one of the major 
concerns for these structures (DSI 2010). Hence, the reliable prediction of sediment loads for these rivers is vital.

The purpose of this study is to propose the reliable empirical method(s) for predicting suspended sediment loads in these three major rivers. For this reason, field and laboratory work for determining the characteristics of sediment and catchments are carried out. Furthermore, a regional analysis is performed in order to suggest proper methods to predict SSLs at a larger scale. This study fills a major gap in the sense that it suggests the appropriate empirical model(s) for suspended sediment rate prediction for the three major rivers of the Aegean Region in Turkey. In addition, for the same region, it suggests the proper empirical and expert methods for estimating sediment loads in a regional basis.

\section{Material and Methods}

Empirical approaches were generally derived from laboratory experiments. It may be necessary to calibrate these models for field conditions. For example, Yang et al. calibrated the unit stream power approach for the Yellow River in China (Yang et al. 1996). There are numerous empirical equations which perform SSL markedly different, even for the same flow and sediment conditions (Yang et al. 2009; Tayfur 2003)

Among, there are basically four major empirical equations for the suspended sediment (Yang 1996) and these are summarized in the following section. Note that, in the derivation of all these empirical relations, it is assumed that the momentum diffusion coefficient for sediment is equal to the momentum diffusion coefficient for fluid $(\beta=1)$ and the Prandtl-von Karman universal constant $(k)$ is 0.4 (Yang 1996). The details of whole empirical approaches below can be found in the text books (Graf 1984; Simons and Senturk 1992; Yang 1996; Julien 2002, among many).

\subsection{Lane and Kalinske's Approach (1941)}

This relation is presented by Eq. (1) as follows (Yang 1996):

$$
q_{s w}=q C_{a} P_{L} \exp \left(\frac{15 \omega a}{U * D}\right)
$$

where; $q_{s w}=$ suspended load rate per meter in terms of weight $\left(\left(\mathrm{MT}^{-1}\right) / \mathrm{L}\right), q=$ unit water discharge $\left(\left(\mathrm{L}^{3} / \mathrm{T}\right) / \mathrm{L}\right), C_{a}=$ suspended sediment concentrations at distance $a$ (sediment concentration above the bed layer) $\left(\mathrm{ML}^{-3}\right), a=2 * d_{b 50}$ the thickness of bed layer (L), $\left(d_{b 50}\right.$; mean particle diameter of bed load) $(\mathrm{L}), U_{*}=$ shear velocity $\left(\mathrm{LT}^{-1}\right), \omega=$ fall velocity $\left(\mathrm{LT}^{-1}\right), D=$ water depth $(\mathrm{L}), P_{L}=\bar{C} / C_{a}$ ratio due to Manning roughness coefficient, where $\bar{C}=$ depth-integrated sediment concentration.

The relationship between $P_{L}$ and $\omega / U_{*}$ is given in a standard chart in Yang ((1996), page 129). One using $D, n$ (Manning roughness coefficient), $\omega$, and $U_{*}$ from the chart finds value of $P_{L}$ and then by Eq. (1) estimates the sediment rate $q_{s w}$.

This approach assumes that momentum diffusion coefficient for sediment $\left(\varepsilon_{s}\right)$, which is a function of depth, is equal to the kinematic eddy viscosity of fluid $\left(\varepsilon_{m}\right)$ (Yang 1996). This approach requires the prior information of $C_{a}$ for the application. 


\subsection{Einstein's Approach (1950)}

The equation developed by H. Albert Einstein in 1950 is (Yang 1996):

$$
q_{s w}=11.6 . U * C_{a} a\left[\left(2.303 \log \frac{30.2 D}{\Delta}\right) I_{1}+I_{2}\right]
$$

where $\Delta=\frac{d_{b 65}}{X}$.

In order to determine $\Delta$, first $\frac{k_{s}}{\delta}=\frac{U * d_{665}}{11.6 v}$ is calculated and then correction factor $X$ is read from the related standard chart in Yang ((1996), page 71) where $v=$ kinematic viscosity $\left(\mathrm{L}^{2} \mathrm{~T}^{-1}\right)$ and $\mathrm{d}_{\mathrm{b} 65}$ is particle size at which $65 \%$ of the bed material by weight is finer. In this approach, $a=2 * d_{b 65}$ (Einstein's approach takes into account $d_{b 65}$ instead of $d_{b 50}$ ). The values of $I_{1}$ and $I_{2}$ in terms of $A$ (i.e., $A=2 d_{b 65} / D$ ) for values of $Z$ (i.e., $Z=\omega /$ $\left.k U_{*}\right)$ can be obtained from the related standard charts in Yang ((1996), pages 131-132).

This approach assumes that momentum diffusion coefficient $(\beta)$ is equal to unity and Prandtl-von Karman universal constant $(k)$ is 0.4 (Yang 1996).

\subsection{Brooks' Approach (1963)}

This approach assumes that the logarithmic velocity distribution is applicable and the vertical sediment concentration follows Eq. (3) (Yang 1996):

where

$$
\begin{gathered}
\frac{C_{m d}}{C_{a}}=\left(\frac{D-y}{y} \frac{a}{D-a}\right)^{Z_{1}} \\
Z_{1}=Z / \beta
\end{gathered}
$$

where $\beta$ is a proportionality factor. In Brook's approach, a reference sediment concentration $\left(C_{m d}\right)$ at $(y=D / 2)$ is required. The rate of $q_{s W} /\left(q C_{m d}\right)$ can be determined from the related standard chart in Yang ((1996), page 13) as a function of $k V / U_{*}$ (where $V$ is the flow velocity) and $Z_{1}$.

\subsection{Chang, Simons and Richardson's Approach (1965)}

In this approach, suspended sediment rate can be determined by Eq. (5) (Yang 1996):

$$
q_{S W}=\gamma D C_{a}\left(V I_{1}-\frac{2 U *}{k} I_{2}\right)
$$

where $\gamma$ is the specific weight of water $\left(\mathrm{ML}^{-3}\right), I_{1}$ and $I_{2}$ values are related to $\xi_{a}=a / D$ and $\mathrm{z}_{2}$ $\left(z=2 \omega / \beta k u_{*}\right)$ that can be determined from the related standard charts in Yang ((1996), pages 135-136) where $\xi_{a}$ represents the ratio of the thickness of bed load. This approach assumes that that momentum diffusion coefficient for sediment $\left(\varepsilon_{s}\right)$ is equal to the kinematic eddy viscosity of fluid $\left(\varepsilon_{m}\right)$ (Yang 1996). 


\subsection{Parameters in Empirical Approaches}

We need to determine some parameters used in the empirical approaches. The suspended sediment concentration above the bed $\left(C_{a}\right)$ is determined by Eq. (6):

$$
C_{a}=\frac{i_{B W} q_{B W}}{11.6 a U_{*}}
$$

where $i_{B W} q_{B W}$ is the bed-load transport rate by weight of size $i_{B W}$. The bed load rate can be computed by the Meyer-Peter's approach, which can be expressed as, using the metric system (Yang 1996):

$$
\frac{0.4 q_{B W}^{2 / 3}}{d_{b}}=\frac{q^{2 / 3} S}{d_{b}}-17
$$

where $q_{B W}$ is the bed-load rate $\left(\mathrm{MT}^{-1} \mathrm{~L}^{-1}\right)$ and $S$ is the bed slope.

Fall velocity $(\omega)$ is an important parameter to investigate the transport of the suspended sediment particles and the aggregation problems in the river engineering. The fall velocity reflects the integrated result of size, shape, surface roughness, specific gravity, viscosity, and temperature of fluid. In the literature, there are some equations, such as Stokes, Newton, and Rubey, for the fall velocity (Graf 1984; Yang 1996). New studies on fall velocity can be found in Dietrich (1982) and Jimanez and Madson (2003). For the fall velocity, Eq. (8) is considered in this study (Julien 2002).

$$
\omega=\frac{8 v}{d}\left\{\left[1+\frac{\left(\gamma_{\mathrm{s}} / \gamma-1\right) \mathrm{g}}{72 v^{2}} \mathrm{~d}^{3}\right]^{1 / 2}-1\right\}
$$

where $d=$ particle size of suspended material $(\mathrm{L}), \gamma_{s}=$ specific weight of sediment $\left(\mathrm{ML}^{-3}\right)$.

Another parameter in the empirical approaches is the shear velocity $\left(U_{*}\right)$ which is computed by Eq. (9) as:

$$
U *=\sqrt{g R S}
$$

where $g=$ gravitational acceleration $\left(\mathrm{LT}^{-2}\right)$, and $R=$ hydraulic radius $(\mathrm{L})$.

\section{Case Study: Aegean Region}

The Aegean Region is located in the western part of Turkey, bounded by the Aegean Sea on the west, the Marmara region on the north, the Mediterranean region on the south and the Southwest and the Central Anatolia regions on the east (Fig. 1). The region occupies about $11 \%$ of the total area of Turkey with approximately 85 thousand square kilometers of land.

There are three main river basins in the region (see Fig. 1). The Gediz, whose length is $401 \mathrm{~km}$, originates from the western Central Anatolia and flows into the Izmir Gulf. 
The Kucuk Menderes is $175 \mathrm{~km}$ long and flows into the Aegean Sea in Selcuk. The Buyuk Menderes is the longest river of the region with a length of $584 \mathrm{~km}$.

The climate of the Aegean coastal zones is similar to the Mediterranean climate; with mild springs, hot summers and warm winters. The Aegean Region has perpendicular mountains along its shores and many valleys between them, thus permitting the sea climate to reach to the inner parts of the region, although some of the provinces inland show also characteristics of Continental climate. The precipitation in the Aegean Region falls between November and April. The annual total precipitation in the region is between 500 and $1000 \mathrm{~mm}$. Generally the coldest month in the region is January and the hottest is July. The peak river flows occur in February or March. Since 1990, however, there has been a persistent decline in surface water flows.

There are four major cities in the region namely Izmir, Usak, Denizli and Manisa. The region is both industrialized and agriculturalized. Main products are textile, leather, carpet production, food, machinery and spare parts, marble, tobacco, sugar, olives and olive oil (Ulke et al. 2009; Ulke et al. 2011).

\subsection{Description of the Gauging Stations}

There are three major rivers in the Aegean Region and four gauging stations run by EIE to meaure flow, suspended sediment, and cross section measurements since 1971. Flow measurements are carried out with current meter. Flow rating curves are then prepared and the water level recorder's measurements are calibrated. The suspended sediment concentration measurements are performed by USDH-48 (Ulke et al. 2011). The USD-49 is used when the river stage is higher than the height of a person (EIE 2010).

There are two gauging stations on the Gediz. 523-Acisu Station, which is located at the upstream of Demirkopru Dam, and 518-Manisa Bridge, which is located at the downstream of the dam (Fig. 1). 523-Acisu whose eleveation is $373 \mathrm{~m}$ and 518 Manisa Bridge Stations whose elevation is $23 \mathrm{~m}$ have drainage areas of about $3272 \mathrm{~km}^{2}$ and $15,614 \mathrm{~km}^{2}$, respectively.

The total annual precipitation is about $624 \mathrm{~mm}$ near the 523-Acisu station, and the mean flow is $10 \mathrm{~m}^{3} / \mathrm{s}$. The measured maximum and minimum sediment loads are respectively 98,401 and $0.14 \mathrm{t}$. The mean soil characteristics in this river section are: $55.9 \%$ sand and $44.1 \%$ clay and silt. The total annual SSL measured in this station is approximately 236 thousand ton and the annual transport rate of SSL is $72 \mathrm{t} / \mathrm{km}^{2}$.

The other station on the Gediz is 518-Manisa Koprusu Station (Fig. 1) where the mean flow rate and total annual precipitation are about $41 \mathrm{~m} / 3$, and $684 \mathrm{~mm}$, respectively. The measured maximum and minimum sediment loads are respectively 35,060 and 0.32 t. The mean soil characteristics in this river section are: $58.1 \%$ sand and $41.9 \%$ clay and silt. The total annual SSL measured in this station is approximately 388 thousand ton and the annual transport rate is $25 \mathrm{t} / \mathrm{km}^{2}$. 518-Manisa Bridge Station was closed down in 2001 (EIE 2006).

601-Selcuk Station, which is on the Kucuk Menderes River, (Fig. 1) has an elevation of $4 \mathrm{~m}$ and a drainage area of $3255 \mathrm{~km}^{2}$. The mean flow and total annual precipitation are about $18 \mathrm{~m}^{3} / \mathrm{s}$ and $674 \mathrm{~mm}$, respectively. The measured maximum and minimum sediment loads are respectively 35,506 and 0.30 t. The mean characteristics soil in this river section is: $62.2 \%$ sand and $37.8 \%$ clay and silt. The total annual SSL measured 
in this station is approximately 197 thousand ton and the annual transport rate of SSL is about $60 \mathrm{t} / \mathrm{km}^{2}$.

701-Kayirli Station, which is on the Cine Stream, a branch of the Buyuk Menderes (Fig. 1) has a drainage area of $948 \mathrm{~km}^{2}$, a total annual precipitation of $647 \mathrm{~mm}$, an elevation of $362 \mathrm{~m}$ and a mean flow rate of about $6.5 \mathrm{~m}^{3} / \mathrm{s}$. The measured maximum and minimum sediment loads are respectively 18,682 and $0.15 \mathrm{t}$. The main characteristics of the soil in this river section are: $50.4 \%$ sand and $49.6 \%$ clay and silt. The total annual SSL measured in this station is approximately 27 thousand ton and the annual transport rate is $28 \mathrm{t} / \mathrm{km}^{2}$.

\subsection{Data Collection and Analysis}

In addition to the flow and the suspended sediment load data the specific weight of the suspended sediment, the size of the transported material, the cross-section, the slope, and the Manning roughness coefficient $(n)$ information are required in the empirical approaches. The soil samples from the suspension phases and the bed layers were obtained from each river sections between 2007 and 2009 in rainy seasons in order to provide the particle diameter and the specific weight information. Three different analysis - specific weight (ASTM-D854 standard), sieve analysis (ASTM-D422) with hydrometry, and consistency limit experiments (ASTM-D4318)-were performed to obtain certain characteristics like the specific weight, the particle size distribution and the consistency of bed material, respectively. The sizes of the suspended load materials were determined by Malvern Mastersizer 2000 equipment. The longitudinal slopes of the stations were obtained from digital maps. The parameters taken from the land surveying and the Manning roughness coefficient $(n)$, determined from the field (Chaudhry 1993), for each river section are presented in Table 1. The sediment characteristics obtained from the laboratory analysis for each station are summarized in Table 2.

The cross-section information and average velocities of the flow related to the rivers were obtained from EIE Aydin Office. Using the existing rating curves of the river sections, the flow depths were first determined. Then, the related cross sectional area $(A)$, the wetted perimeter $(P)$ and the water surface width $(B)$ were obtained from the cross-section drawings. Since the mean velocity and discharge data for the river sections were already available, the accuracy of the cross sections was first checked by comparing the measured cross sectional areas with the computed ones. Some cross sections were found not to be compatible with the measured ones. Hence, we computed the ratios of the measured and computed cross section areas and took into consideration the ones having the ratios more than about $70 \%$ (see Table 3 ).

Table 1 Parameters for Gediz, Kucuk Menderes and Buyuk Menderes rivers

\begin{tabular}{lllll}
\hline Parameters & \multicolumn{2}{l}{ Stations } & & \\
\cline { 2 - 5 } & 523 - Acisu & 518- Manisa Koprusu & 601- Selcuk & 701- Cine Cayı Kayirli \\
\hline Longitudinally slope (S) & $\% 0.3$ & $\% 0.08$ & $\% 0.06$ & $\% 0.5$ \\
Manning roughness coefficient $(n)$ & 0.04 & 0.025 & 0.025 & 0.035 \\
\hline
\end{tabular}




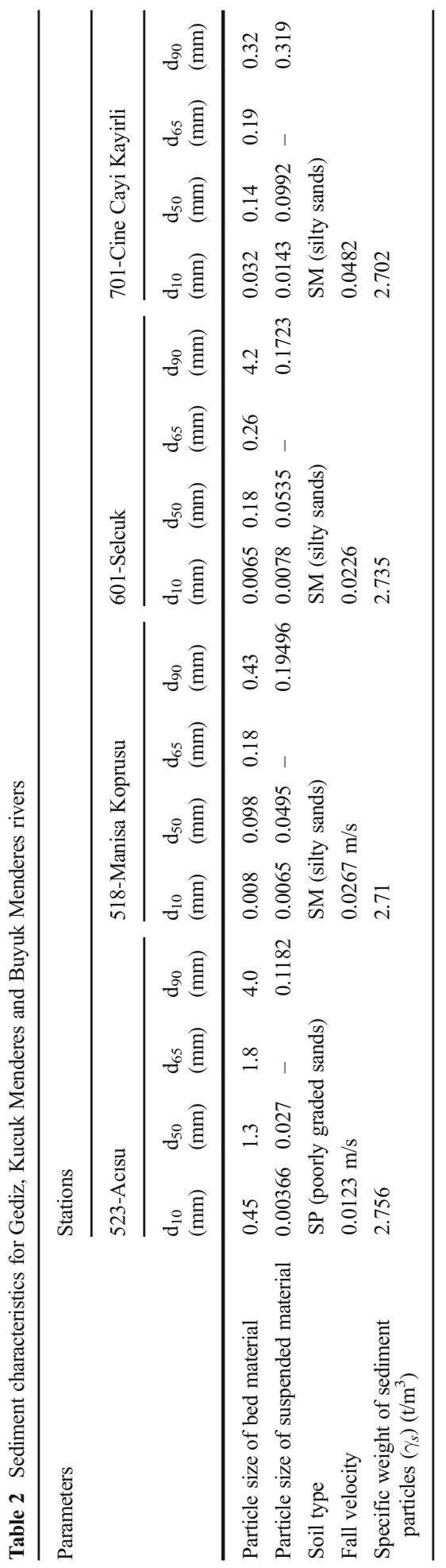




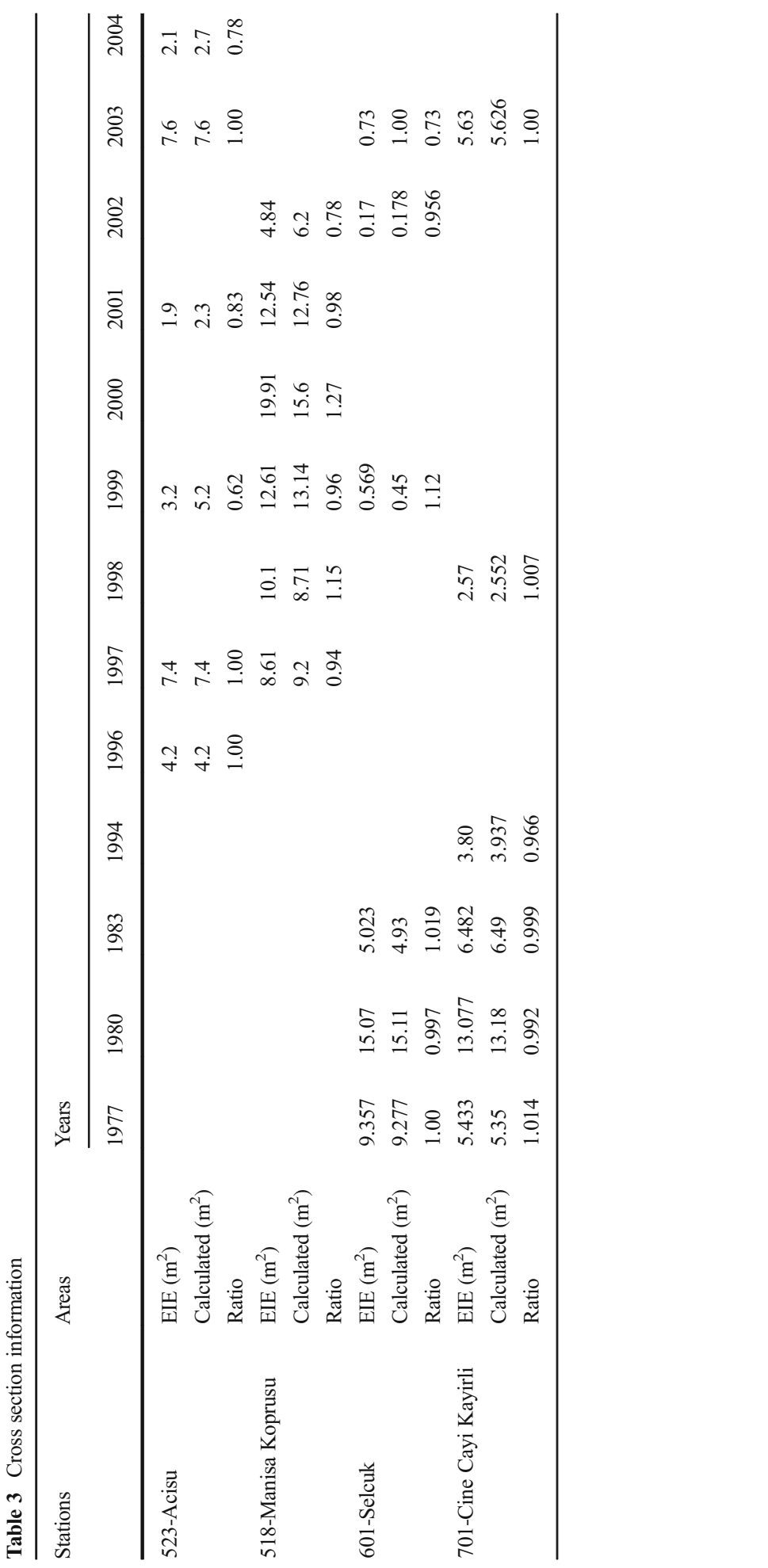




\section{Applications of the Artificial Intelligence Methods}

\subsection{Artificial Neural Network (ANN)}

ANN is essentially a "black box" operation mapping input data onto output data using a particular set of nonlinear basis functions. Neurons, which are the basic units, are connected to each other by links known as synapses. Associated with each synapse, there is a weighting factor. Back propagation method is generally used for training the feed-forward neural networks (FFNN) using a set of pairs of input and output values. Each neuron at input and inner layers receives input values, processes them and then passes the response to the next layer (ASCE 2000). A FFNN can have one or more hidden layer, whose computation nodes are correspondingly called hidden neurons of hidden units. The function of hidden neurons in the hidden layer is to intervene between the external input and the network output in some manner. A FFNN network structure was shown in Fig. 2. The detailed theoretical information about FFNN can be found in Haykin (1998); Cybenco (1989); ASCE (2000); and Tayfur (2012).

In the present study, a one-hidden-layer and Conjuge Gradient optimization technique is used.

\subsection{Adaptive Neuro-Fuzzy Inference System (ANFIS)}

An ANFIS is a network structure consisting of a number of nodes connected through directional links. Each node is characterized by a function. These functions have fixed or adjustable parameters. The aim of this structure is to determine the sufficient parameters which fit the training data set. Jang (1993) introduced for the first time an architecture and a learning procedure for the fuzzy inference systems (FIS) that uses a neural network learning algorithm for constructing a set of fuzzy IF-THEN rules with appropriate membership functions (MFs) from the specified input-output pairs. This procedure of developing a FIS using the framework of adaptive neural networks is called an adaptive neuro-fuzzy inference system (ANFIS). The detailed theoretical information about ANFIS can be found in Jang (1993). An ANFIS structure was shown in Fig. 3.

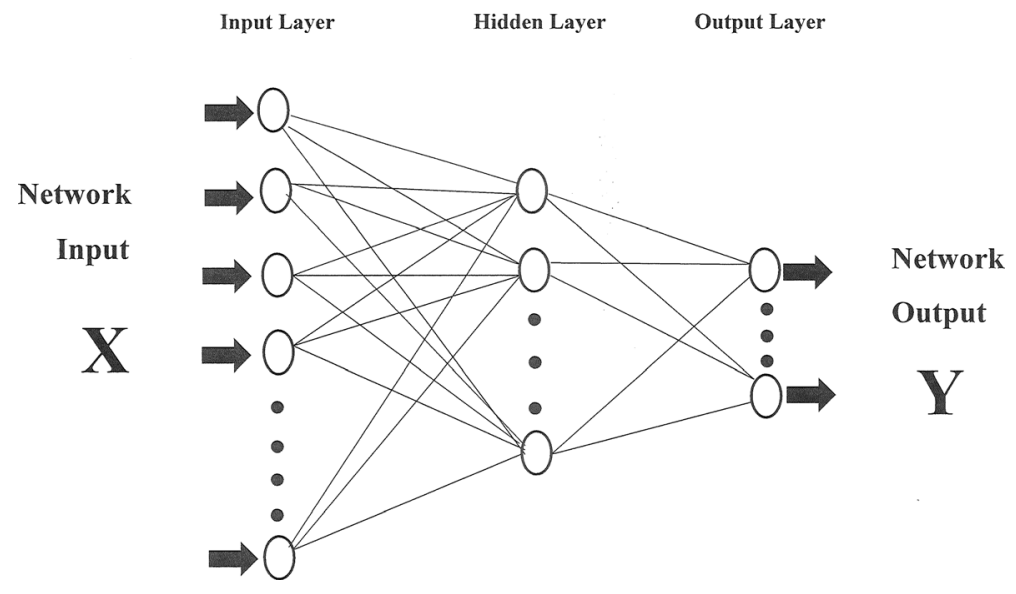

Fig. 2 ANN architecture 


\section{Applications of the Empirical Approaches}

The empirical approaches were applied to data measured in years in Table 3 where the cross sectional area ratios are greater than $70 \%$. Accordingly, there were 63, 68, 60 and 73 data sets exist for 523, 518, 601 and 701 stations, respectively. The results of empirical approaches are presented in Table 4. As seen, all the models over-predicted the total load. Brooks and Chang, Simons \& Richardson approaches did under-prediction of the total load only in 518-Manisa Koprusu Station. Also, in Table 4, MAE (mean absolute error), MARE (mean absolute relative error) and CME (cumulative error) are given. All the empirical approaches yielded high errors considerably. However, when especially CME and total load estimate performances are analyzed, it can be seen that Brooks' method shows better performance than the others.

It is not a surprise that the empirical methods in Table 4 produced large errors. Yang (1996) discussed and showed that the models could produce markedly different results for the same example with many other magnitudes (see Tayfur 2003). There may be several reasons for the drastic difference among models in predicting suspended sediment loads: 1) Empirical approaches were derived from laboratory experiments. Hence, they can perform better for the conditions from which they are derived. Since laboratory experiments cannot determine the natural conditions definitely, it is natural to expect poor performances when they are applied to field situations; 2) There is a lack of well defined strong correlation between concentration and a dominant variable such as the flow discharge, the shear-stress, the stream power, or the unit stream power; 3) It is difficult to find out the particle fall velocity; 4) The boundary is movable and the resistance to flow is variable; 5) The sediment transport also depends on: The gradation and the shape of sediment, the availability of material for transport, the variations of hydrological cycle, the rate of supply of fine material or wash load, the water temperature, the channel pattern and the bed configuration, the strength of turbulence, etc., (Yang 1996; Tayfur 2003). Apart from them, tremendous uncertainties are involved in estimating the sediment load at different flows and the sediment conditions under different hydrological, geological and climatological constraints.

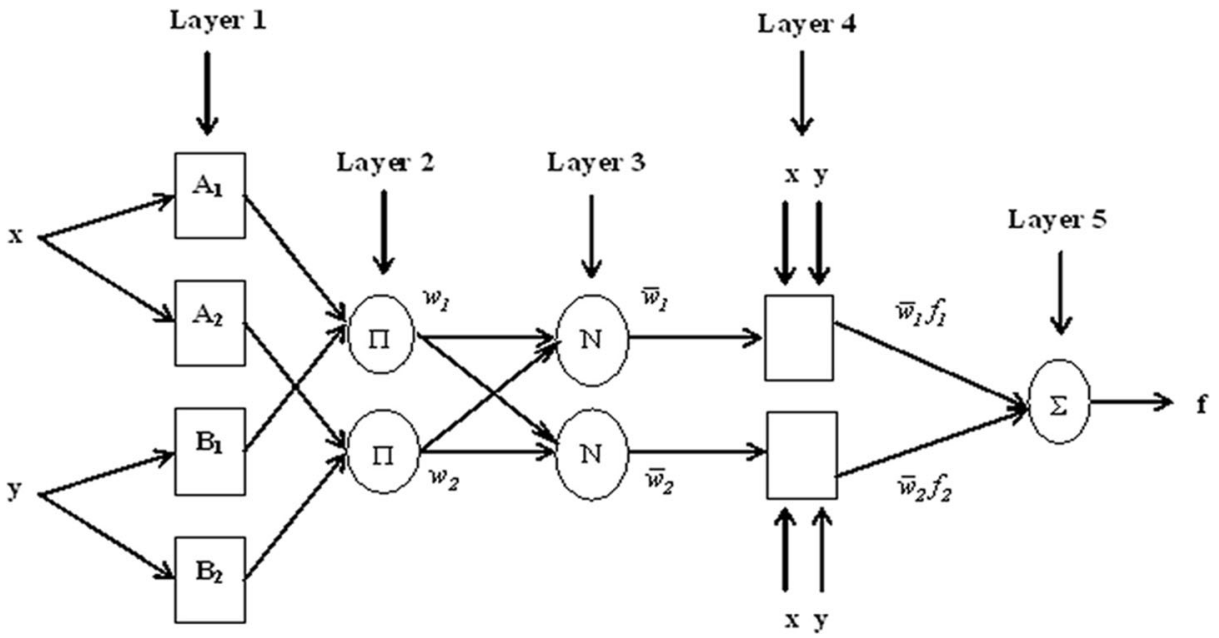

Fig. 3 ANFIS architecture 
The application of the empirical methods to 3 major rivers in the Aegean Region involved also all these uncertainties and the hydrological, geological, and the climatological constraints, resulting in high MAE, MARE, and CME values in Table 4. However, Brooks' method, compared with other 3 approaches, produced relatively low error values (Table 4). For example; for 518-Manisa Koprusu and 601-Selcuk stations, it made on the average $30 \%$ error, which can be considered reasonable. Although Brook's method gave bad results for 523Acisu and 701-Cine Cayi stations, when compared with other three method, it was understood that this method was better than others (see Table 4). Hence, we may state that Brooks' method may be more appropriate, among the other empirical methods, to predict suspended sediment loads in the major rivers in the Aegean region.

Among 4 empirical methods, Brooks' method produced better estimates, as discussed above. However, the performance of the model was not at a desired level (see Table 4) since the error values were high. That is the reason that we decided to improve its performance.

\section{Improvement of Brooks' Method by Genetic Algorithm}

The performance improvement of Brooks' method was carried out using the genetic algorithm, which is a nonlinear search and optimization method inspired by biological processes of natural selection and the survival of the fittest. It makes relatively a few assumptions and doesn't rely on mathematical properties of the functions such as differentiability and continuity and this makes it more generally applicable and robust (Goldberg 1989, 1999; Liong et al.

Table 4 Results of empirical approaches for the stations

\begin{tabular}{|c|c|c|c|c|c|c|}
\hline Stations & Models & $\begin{array}{l}\text { MAE } \\
\text { t/day }\end{array}$ & $\begin{array}{l}\text { MARE } \\
\%\end{array}$ & $\begin{array}{l}\text { CME } \\
\%\end{array}$ & $\begin{array}{l}\sum \text { model } \\
\text { load ton }\end{array}$ & $\begin{array}{l}\sum \text { observed load } \\
\text { ton }\end{array}$ \\
\hline \multirow[t]{4}{*}{ 523-Acisu } & Lane\&Kalinske & 11,405 & 3855 & -1931 & 755,698 & 37,205 \\
\hline & Einstein & 11,259 & 10,428 & -1906 & 746,515 & 37,205 \\
\hline & Brooks & 4200 & 1245 & -680 & 290,237 & 37,205 \\
\hline & $\begin{array}{l}\text { Chang, Simons } \\
\text { \& Richardson }\end{array}$ & 5940 & 1696 & -970 & 398,185 & 37,205 \\
\hline \multirow{4}{*}{$\begin{array}{c}\text { 518-Manisa } \\
\text { Koprusu }\end{array}$} & Lane\&Kalinske & 286,805 & 22,560 & $-12,695$ & $19,656,387$ & 153,626 \\
\hline & Einstein & 13,543 & 1866 & -595 & $1,067,557$ & 153,626 \\
\hline & Brooks & 1425 & 73 & 50 & 76,444 & 153,626 \\
\hline & $\begin{array}{l}\text { Chang, Simons \& } \\
\text { Richardson }\end{array}$ & 1796 & 104 & 63 & 57,222 & 153,626 \\
\hline \multirow[t]{4}{*}{ 601-Selcuk } & Lane\&Kalinske & 123,787 & 23,420 & -7524 & $7,525,945$ & 98,704 \\
\hline & Einstein & 15,088 & 2385 & -917 & $1,003,775$ & 98,704 \\
\hline & Brooks & 2942 & 837 & -24 & 122,272 & 98,704 \\
\hline & $\begin{array}{l}\text { Chang, Simons \& } \\
\text { Richardson }\end{array}$ & 2987 & 911 & -128 & 225,004 & 98,704 \\
\hline \multirow{4}{*}{$\begin{array}{l}\text { 701-Cine Cayi } \\
\text { Kayirli }\end{array}$} & Lane\&Kalinske & 389,520 & 465,929 & $-67,239$ & $28,477,198$ & 42,290 \\
\hline & Einstein & 230,058 & 191,230 & $-39,712$ & $16,836,538$ & 42,290 \\
\hline & Brooks & 6257 & 2143 & -1080 & 499,048 & 42,290 \\
\hline & $\begin{array}{l}\text { Chang, Simons } \\
\text { \& Richardson }\end{array}$ & 7120 & 2459 & -1485 & 670,503 & 42,290 \\
\hline
\end{tabular}


Table 5 Number of data sets in the calibration and testing and the optimal value of the calibration coefficient

\begin{tabular}{lllll}
\hline Stations & \# of whole data sets & \# of calibration data sets & \# of testing data sets & $F_{c}$ \\
\hline 523-Acisu & 63 & 42 & 21 & 0.0636 \\
518-Manisa Koprusu & 68 & 48 & 20 & 1.096 \\
601-Selcuk & 60 & 41 & 19 & 0.5431 \\
701-Cine Cayi Kayirli & 73 & 50 & 23 & 0.0591 \\
\hline
\end{tabular}

1995; Sen 2004). Basic units of GA consist of 'bit', 'gene', 'chromosome' and 'gene pool'. Gene consisting of bits ( 0 and 1$)$ represents a model parameter (or a decision variable) to be optimized. The combination of genes forms the chromosome, each of which is a possible solution for each variable. Finally, a set of chromosomes form the gene pool. The main GA operations basically consist of 'generation of initial gene pool', 'evaluation of fitness for each chromosome', 'selection', 'cross-over', and 'mutation'. The details of GA can be obtained from Goldberg (1999), Sen (2004) and Tayfur (2012).

GA has found a wide application in water resources engineering recently due to its outperforming performance (Sen and Oztopal 2001; Jain et al. 2004; Guan and Aral 2005; Singh and Datta 2006; Tayfur and Moramarco 2008; Tayfur 2009; Tayfur et al. 2009; Tayfur and Singh 2011, etc.). The details of GA applications are given in Tayfur (2012), which clearly present the advantages of GA as an optimization method in solving hydraulic engineering problems. That is the reason why it is employed in this study to obtain the optimal value of coefficient $F_{c}$ in following Eq. (10).

$$
q_{S W G A-B r o o k s}=F_{c} * q_{S W \_B r o o k s}
$$

where; $q_{S W \text { Brooks }}$ is the suspended sediment load predicted by Brooks' method, $q_{\text {SWGA-Brooks }}$ is the suspended sediment load predicted by GA_based Brooks method. $F_{c}$ is calibration coefficient whose optimal value is obtained by the genetic algorithm. Note that the

Table 6 Results of all methods in the testing part for the stations

\begin{tabular}{lllllll}
\hline Stations & Models & $\begin{array}{l}\text { MAE } \\
\text { (t/day) }\end{array}$ & MARE \% & CME \% & $\begin{array}{l}\Sigma \text { model load } \\
\text { (ton) }\end{array}$ & $\begin{array}{l}\Sigma \text { observed load } \\
\text { (ton) }\end{array}$ \\
\hline 523-Acisu & GA_Brooks & 528 & 57 & 28 & 13.913 & 19.513 \\
& ANN & 790 & 182 & -59 & 31.062 & 19.513 \\
& ANFIS & 618 & 242 & -20 & 23.464 & 19.513 \\
518-Manisa Koprusu & GA_Brooks & 1202 & 52 & 50 & 23.404 & 46.875 \\
& ANN & 1501 & 99 & 7 & 43.670 & 46.875 \\
601-Selcuk & ANFIS & 2096 & 124 & 15 & 39.727 & 46.875 \\
& GA_Brooks & 786 & 103 & 14 & 18.681 & 21.755 \\
& ANN & 1142 & 812 & -97 & 42.967 & 21.755 \\
701-Cine Cayi & ANFIS & 1017 & 490 & -70 & 37.040 & 21.755 \\
Kayirli & GA_Brooks & 212 & 143 & 18 & 11.910 & 14.532 \\
& ANN & 313 & 444 & 3 & 14.109 & 14.532 \\
& ANFIS & 392 & 1.215 & 53 & 6.815 & 14.532 \\
\hline
\end{tabular}


Table 7 Summary of characteristics for the upstream and downstream stations

\begin{tabular}{|c|c|c|c|c|c|c|c|c|c|}
\hline & Stations & $\begin{array}{l}\text { Elevation } \\
\text { (m) }\end{array}$ & $\begin{array}{l}\text { Net drainage } \\
\text { area }\left(\mathrm{km}^{2}\right)\end{array}$ & $\begin{array}{l}\text { Maximum } \\
\mathrm{Q}\left(\mathrm{m}^{3} / \mathrm{s}\right)\end{array}$ & $\begin{array}{l}\text { Maximum } \\
\text { SSL (t/day) }\end{array}$ & S \% & $\mathrm{n}$ & $\begin{array}{l}\mathrm{d}_{\mathrm{b}} \\
(\mathrm{mm})\end{array}$ & $\begin{array}{l}\mathrm{d} \\
(\mathrm{mm})\end{array}$ \\
\hline \multirow{2}{*}{$\begin{array}{l}\text { Upstream } \\
\text { Stations }\end{array}$} & 523 & 348 & 3273 & 876 & 98,409 & 0.3 & 0.04 & 1.3 & 0.1182 \\
\hline & 701 & 262 & 948 & 250 & 18,682 & 0.5 & 0.035 & 0.14 & 0.319 \\
\hline \multirow{2}{*}{$\begin{array}{c}\text { Downstream } \\
\text { stations }\end{array}$} & 518 & 23 & 15,616 & 559 & 35,060 & 0.08 & 0.025 & 0.098 & 0.19496 \\
\hline & 601 & 4 & 3255 & 614 & 35,506 & 0.06 & 0.025 & 0.18 & 0.1723 \\
\hline
\end{tabular}

performance of Brooks' method whose results are improved by genetic algorithm is called GA_Brooks method in this study.

When obtaining the optimal value of $F_{c}$, the results, obtained by Brooks' method and the corresponding measured data, were divided into two sets - calibration and validation - for each station. For example, 523-Acisu Station has 63 data sets, of which 42 were used in the calibration. The number of data sets used for calibration and validation for each river section is summarized in Table 5.

The calibration parameter was optimized through the minimization of the mean absolute error objective function (the absolute error between prediction and measured data) and summarized in Table 5. As seen, different values were obtained for the coefficient $\left(F_{c}\right)$ for each station. This may be because the flora, the particle size, the longitudinal slope and the water quality substantially varies among the river sections. Furthermore, since 518-Manisa Koprusu Station is located downstream of the Demirkopru Dam (Fig. 1), it is under the regulation effect of the dam. In addition, there are industrial, agricultural and domestic waste in 518-Manisa Koprusu and 601-Selcuk Stations. On the other hand, 701-Cine Cayi, Kayirli Station has well spring contribution.

The performance of the GA_Brooks method was tested against the measured loads and as well as the artificial neural networks (ANN) and adaptive neuro-fuzzy inference system (ANFIS). Table 6 summarizes the comparative results for the four stations. Ulke (2010) had

Table 8 Brooks, GA_Brooks, ANN and ANFIS models for the testing in the Upstream, Downstream and Whole Stations Together approaches

\begin{tabular}{lllllll}
\hline & Models & $\begin{array}{l}\text { MAE } \\
\text { t/day }\end{array}$ & $\begin{array}{l}\text { MARE } \\
\%\end{array}$ & $\begin{array}{l}\text { CME } \\
\%\end{array}$ & $\begin{array}{l}\Sigma \text { model load } \\
\text { ton }\end{array}$ & $\begin{array}{l}\Sigma \text { observed load } \\
\text { ton }\end{array}$ \\
\hline Upstream approach & Brooks & 8780 & 2010 & -1134 & 420,348 & 34,045 \\
& GA_Brooks & 571 & 189 & -43 & 48,638 & 34,045 \\
& ANN & 492 & 1255 & -29 & 44,093 & 34,045 \\
Downstream approach & ANFIS & 950 & 1255 & -27 & 43,458 & 34,045 \\
& Brooks & 941 & 64 & 55 & 23,946 & 53,639 \\
& GA_Brooks & 781 & 62 & 43 & 30,442 & 53,639 \\
& ANN & 1352 & 116 & 23 & 41,300 & 53,639 \\
Whole Stations Together & ANFIS & 1316 & 125 & 8 & 49,372 & 53,639 \\
approach & Brooks & 5053 & 629 & -365 & 400,120 & 86,024 \\
& GA_Brooks & 745 & 99 & -11 & 96,105 & 86,024 \\
& ANN & 947 & 273 & -11 & 95,686 & 86,024 \\
& ANFIS & 823 & 141 & -14 & 98,229 & 86,024 \\
\hline
\end{tabular}




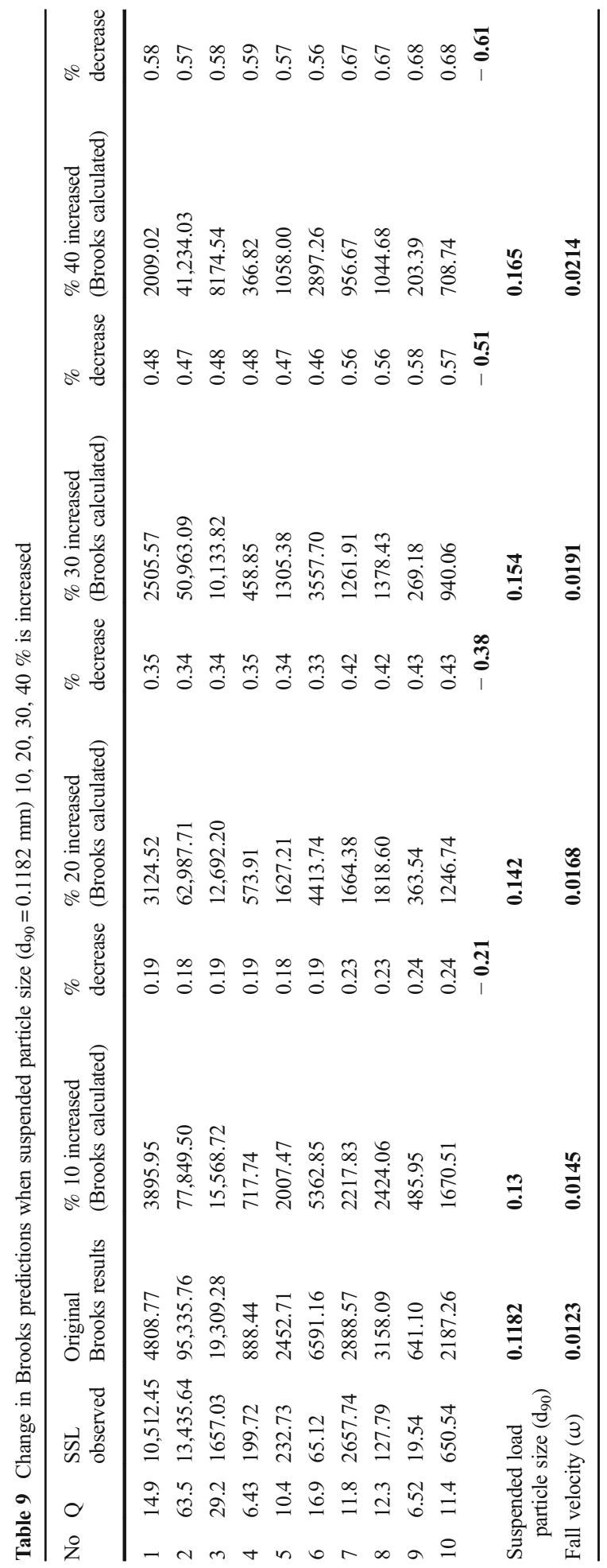


Fig. 4 Change in Brooks predictions when suspended particle size $(\mathrm{d} 90=0.1182 \mathrm{~mm})$ $10,20,30,40 \%$ is increased

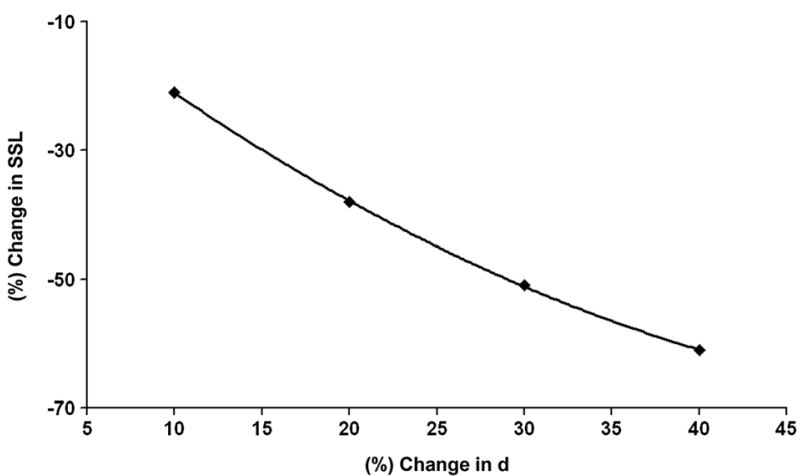

already applied ANN and ANFIS models to predict suspended sediment loads in these 3 major rivers in Aegean Region. The details of ANN, ANFIS and their applications to predict suspended sediment loads can be found in Ulke (2010). The literature has shown many successful applications of ANN and ANFIS in hydraulic engineering problems and their superiority over classical, regression, empirical, and rating curve methods (Ulke et al. 2009; Tayfur 2012; Ulke 2010; ASCE 2000). That is the reason that, in this study, the comparative analysis was carried out with these methods and the measured data. As seen, GA-Brooks method produced results comparable to those of ANN or ANFIS. ANFIS overall showed better performance than others at 523-Acisu Station, followed by GA_Brooks which even produced low errors of MAE and MARE (see Table 6). ANN showed better performance than others for 518-Manisa Koprusu Station. GA_Brooks method was the best among others in predicting sediment loads at 601-Selcuk Station (see Table 6) with respect to total load and as well as minimum error measures. GA_Brooks and ANN models produced lower MAE and MARE errors for the 701-Cine Cay1, Kayirli Station and did the close prediction of the measured total load (see Table 6).

Note that, for the purpose of illustration, $F_{c}$ parameter in Eq. (10) is also optimized by the regression analysis for Station 523, using the calibration data set. Its optimal value is obtained as 0.80 and the application to the testing data set resulted in very large errors-MAE $=1457 \mathrm{t}$ / day, $\mathrm{MARE}=9598 \%$, and $\mathrm{CME}=-115 \%$. This results show the superiority of GA over the regression method.

Also, note that, the data sets for Station 523 were separated into calibration and testing sets as time series periods. 1995-2001 period is used for the calibration (41 sets of data) and 20022004 period as testing (22 sets of data). The optimal value of $F_{c}$ in Eq. (10), using the calibration set, is obtained as 0.086 . The application to the testing period gave satisfactory results with low errors-MAE $304 \mathrm{t} /$ day, $\mathrm{MARE}=104 \%$, and $\mathrm{CME}=-8.1 \%$.

\section{Regional Analysis}

The regional analysis is performed for three cases; (1) the upstream regions, (2) the downstream regions, and (3) the whole region, using Brooks, GA_Broks, ANN, and ANFIS methods. The purpose is to investigate whether one can apply these methods in a regional sense. 


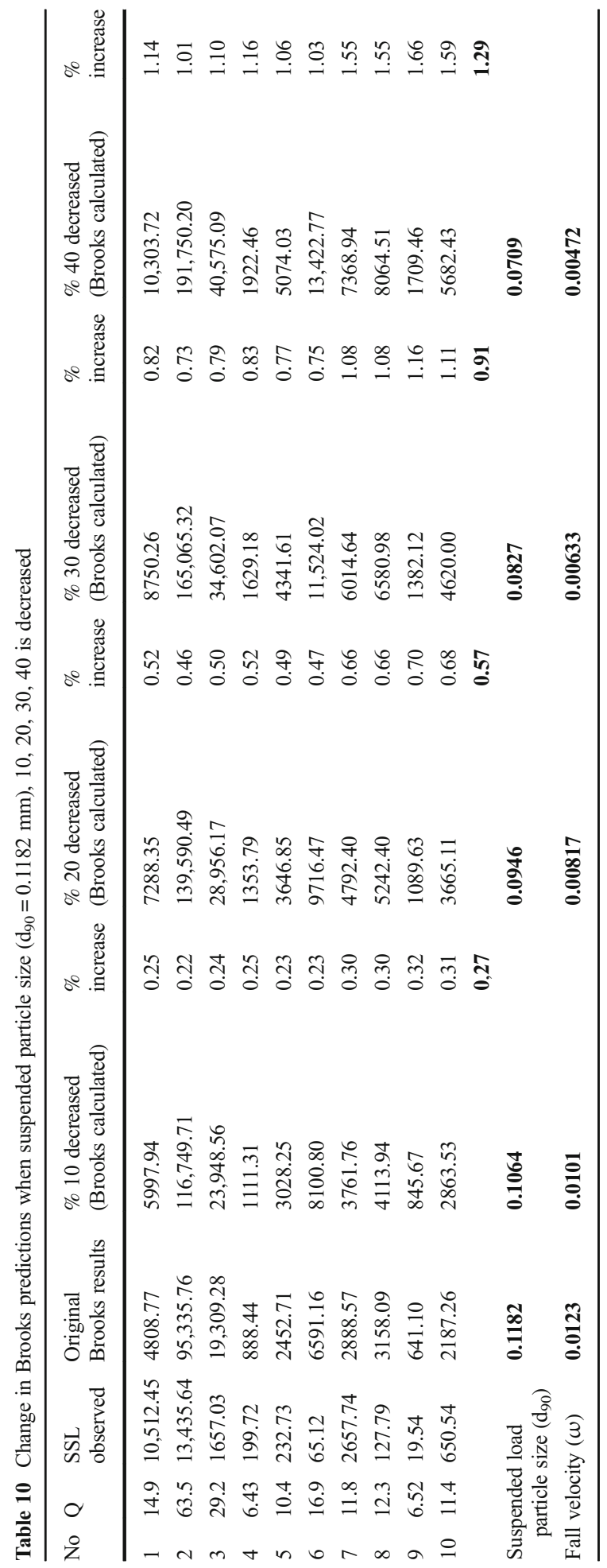


Fig. 5 Change in Brooks predictions when suspended particle size $(\mathrm{d} 90=0.1182 \mathrm{~mm})$, $10,20,30,40 \%$ is decreased

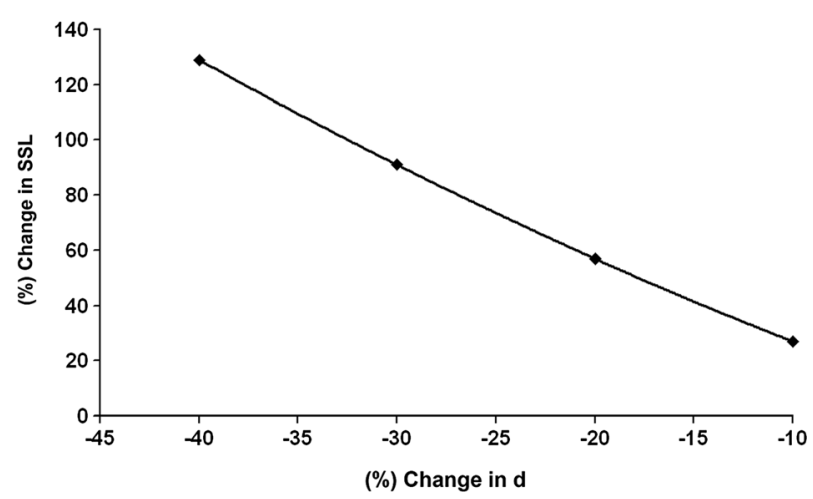

In the analysis, since the sub basins have different topographic and soil characteristics, the values observed at each station show difference in magnitude, resulting in one station becoming dominant over the other station. In order to avoid this problem, the observed values were standardized (squashed) before the calibration of the models. The standardization (compaction) is carried out by simply dividing each observed value by the mean of the corresponding series, (i.e. $z_{i}=x_{i} / x_{\text {mean }}$, where $z_{i}$ is the standardized value, $x_{i}$ is the measured value, $x_{\text {mean }}$ is the mean measured value).

\subsection{Upstream Regional Analysis}

The upstream stations of 523-Acısu Station on the Gediz and 701-Cine Cayi Kayirli Station on the Buyuk Menderes were considered together in the upstream regional analysis. First of all, it is needed to re-summarize all the characteristics of both the station, to evaluate these two stations (Table 7). As seen in Table 7, although the physical characteristics are within the same order, the observed maximum $Q$ and $S S L$ values and the particle size distributions are quite different.

In constructing the upstream regional analysis, 136 data sets from both stations were combined, mixed and then standardized. The data sets of 136, 92 and 44 were used for the calibration and testing, respectively. The calibration coefficient $\left(F_{c}\right)$ for the GA_Brooks was found to be 0.939 . For the sake of the brevity, we do not show the calibration period results. Table 8 shows the testing period results for all the models. As seen in Table 8, GA_Brooks, ANN, ANFIS models, in terms of total load predictions, made an average of $33 \%$ overprediction while the classical Brooks method showed a very poor performance.

\subsection{Downstream Regional Analysis}

The downstream stations of 518-Manisa Köprüsü Station on the Gediz and 601-Selcuk Station on the Kucuk Menderes were considered together in the downstream regional analysis. The summary of downstream station's characteristics is given in Table 7. As seen in Table 7, all of the physical characteristics are within the same order. The observed maximum $Q$ and SSL values and also the particle size distributions at the stations are also closer to each other.

In constructing the downstream regional analysis, 110 data sets from both stations were combined, mixed and then standardized. The data sets of 110, 78 and 32 were used for the 


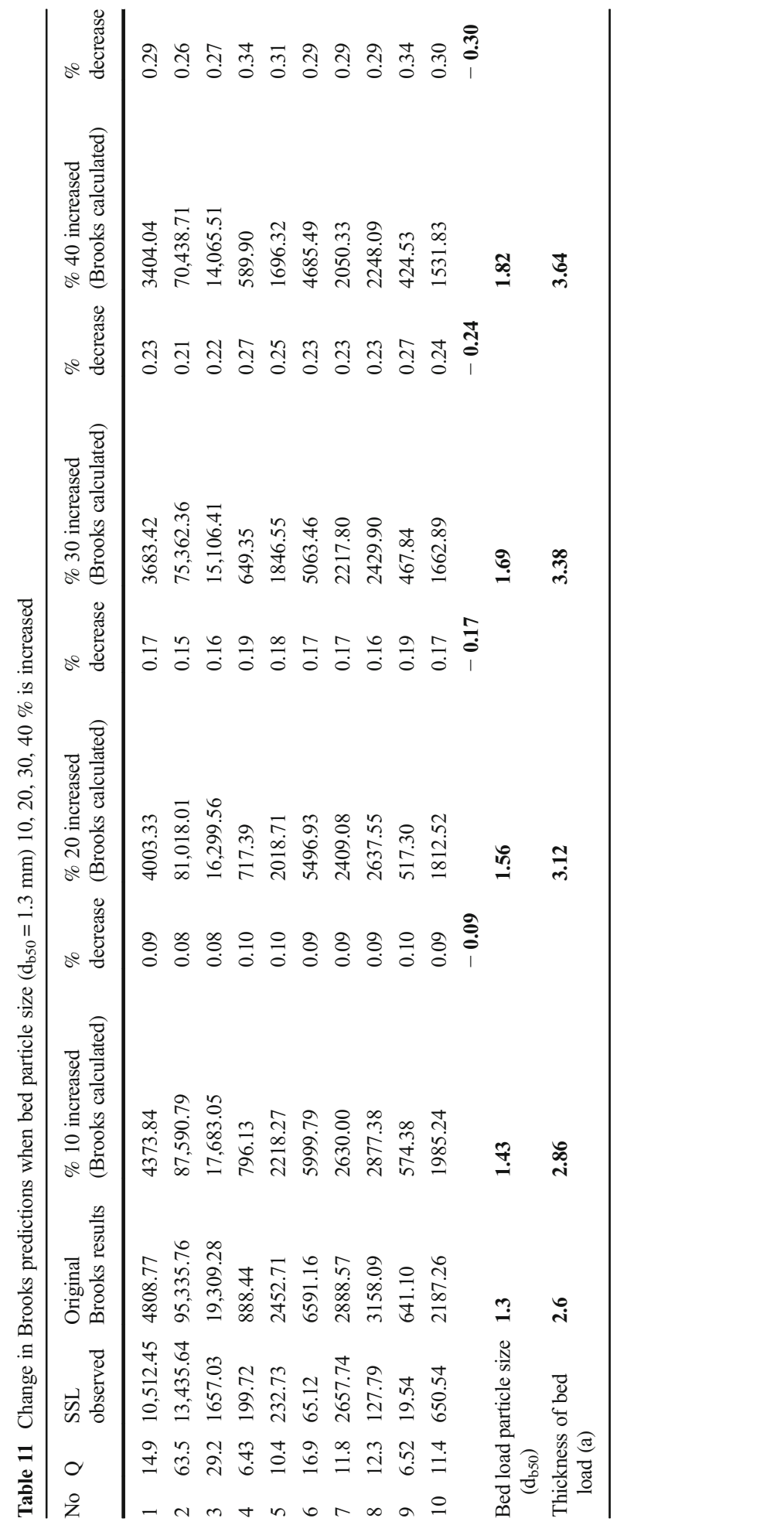


Fig. 6 Change in Brooks predictions when bed particle size $(\mathrm{db} 50=1.3 \mathrm{~mm}) 10,20,30$, $40 \%$ is increased

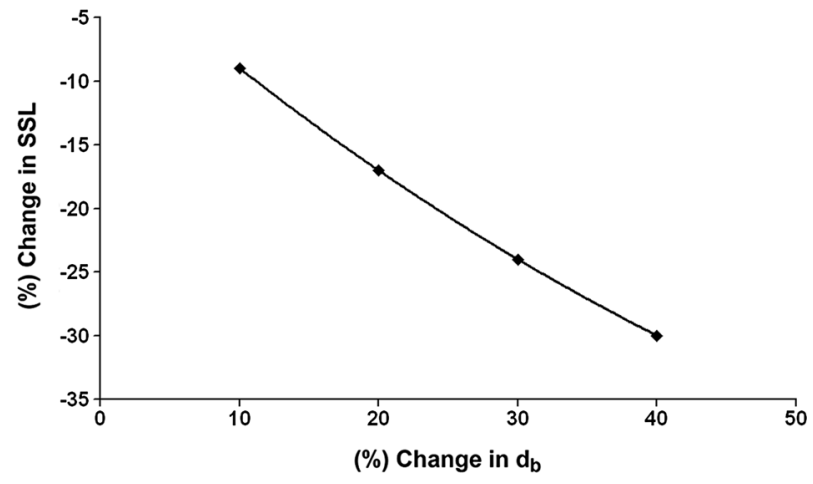

calibration and testing, respectively. The calibration coefficient $\left(F_{c}\right)$ for the GA_Brooks was found to be 0.698 . For the sake of the brevity, we do not show the calibration period results. Table 8 shows the testing period results for all the models. As seen, the ANFIS model showed better performance than others with $8 \%$ error in predicting the total load, followed by ANN (23\% error) and GA_Brooks $(43 \%)$.

\subsection{Regional Approach}

All the four stations were considered in the regional analysis. In constructing the regional analysis, 212 data sets from all the stations were combined, mixed and then standardized. The data sets of 212, 138 and 74 were used for the calibration and testing, respectively. The calibration coefficient $\left(F_{c}\right)$ for the GA_Brooks was found to be 0.822 . For the sake of the brevity, we do not show the calibration period results. Table 8 shows the testing period results for all the models. As seen in Table 8, ANFIS, ANN, GA_Brooks methods predicted total loads with, on the average, less than $12 \%$ error and the classical Brooks method showed very poor performance.

Results above indicate that GA_Brooks, ANN, and ANFIS models can be employed for gross prediction of sediment loads at a regional basis, which may be useful for planning purposes. This is because, although the cumulative load prediction capacity of the models is plausible, there exits high error measures. This is a natural result because even in the same basin, sub basins can show quite different characteristics. Hence, in regional analysis, an attention should be devoted to combining basins which have similar topographic, geographic and soil characteristics.

\section{Sensitivity Analyses}

The empirical approaches used in this study, employed the field particle sizes measured from the collected samples. However, this approach may not consider all the temporal variation in the particle size. This assumption may not be true due to rapid variations in watershed characteristics, and river morphology. Hence, in this section, the effect of particle size on the sediment transport rate was investigated. For this purpose, for the sake of brevity, we only employed 10 data sets from 523 Acisu station. Also, in choosing these data sets, we paid extra attention in order to cover low and high suspended sediment load observations. 


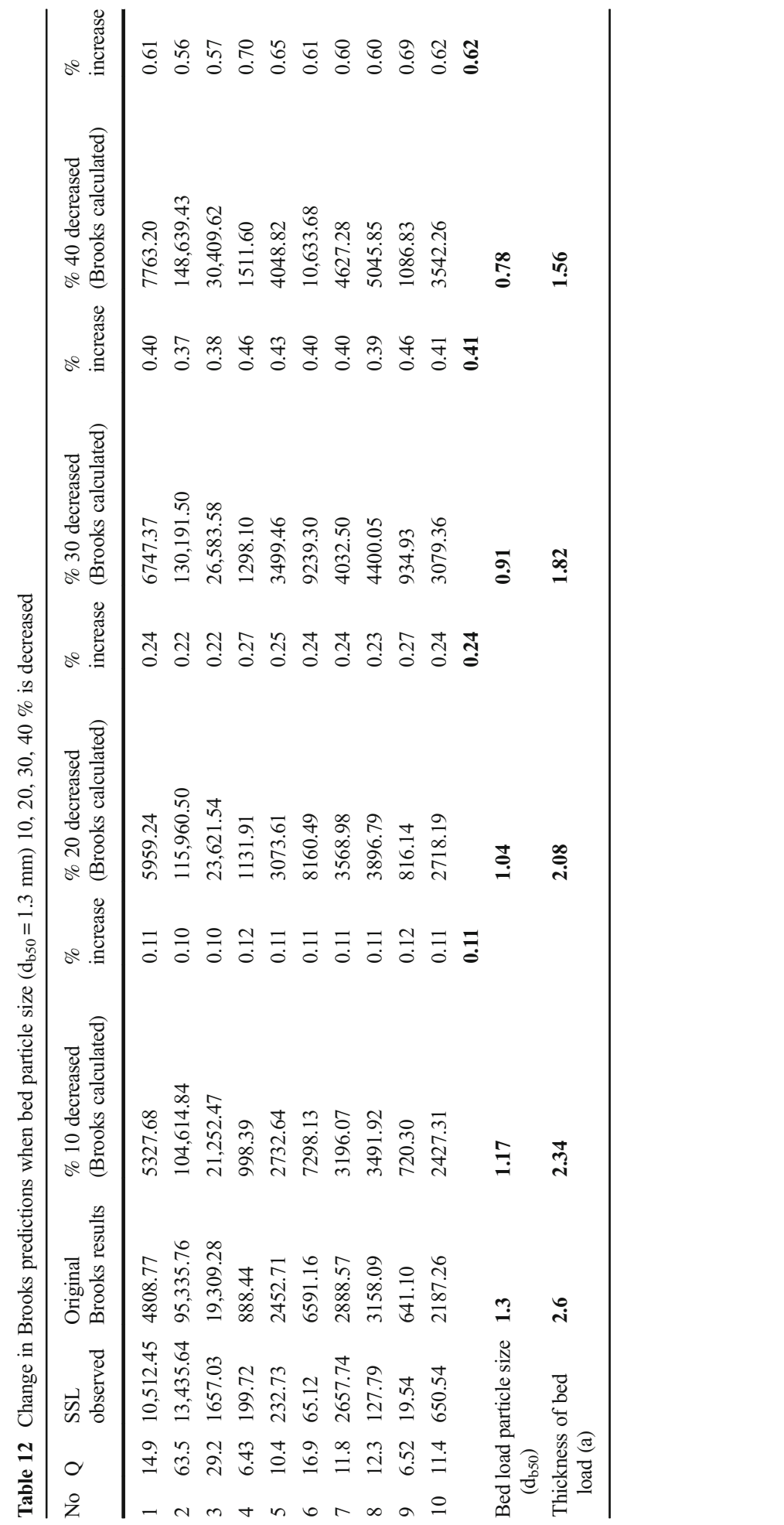


Fig. 7 Change in Brooks predictions when bed particle size $(\mathrm{db} 50=1.3 \mathrm{~mm}) 10,20,30$, $40 \%$ is decreased

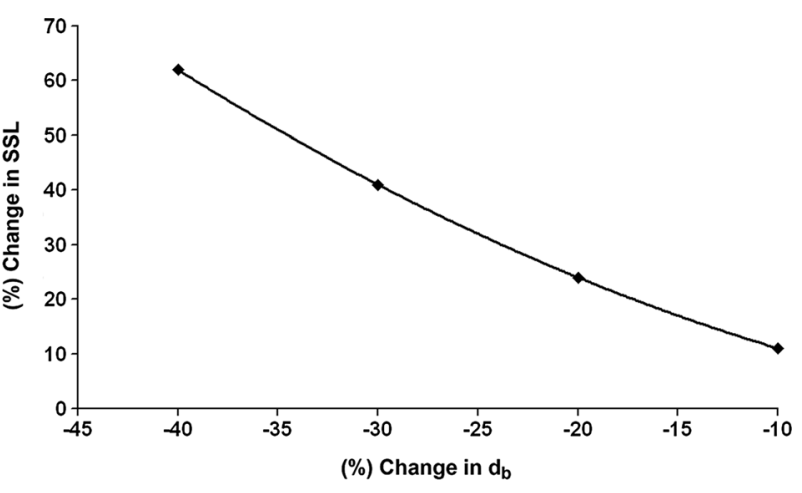

In the sensitivity analysis, the suspended particle size was increased and decreased at a rate of $10,20,30,40 \%$. Note that the particle fall velocity is influenced by the particle size. An increase in the size will lower the transported load in suspension. A decrease in the size of a particle will definitely increase the suspended sediment concentration in the water flow.

Table 9 and Fig. 4 present the sensitivity analysis results for the case of increasing the particle size. As seen, as the particle size increases at a rate of $\% 10,20,30,40$ and the Brooks method results decrease at a rate of 20,38, 50 and $61 \%$, respectively. Table 10 and Fig. 5 show the sensitivity analysis results of decreasing the particle size at a rate of $\% 10,20,30,40 \%$ and the corresponding change in the sediment load predictions. As seen, there is an increase in the predicted load at a rate of $27,57,91$ and $129 \%$, respectively.

As one may remember, $a=2 * d_{b 50}$ which is, in turn, used for the computation of $\mathrm{Ca}$ in the empirical approaches in Section 2. Because of this, the bed load material size was also increased and decreased at a rate of 10,20,30,40\%, to see its effect on the suspended sediment transport. Table 11 and Fig. 6 present the sensitivity analysis results of increasing the bed material. As expected, bed sediment particle size increases at a rate of 10, 20, 30, $40 \%$, causes a decrease of the sediment load at a rate of $9,17,24$ and $30 \%$, respectively. Similarly, as seen in Table 12 and Fig. 7, bed sediment particle size increases at a rate of 10, 20, 30, $40 \%$, results in an increase of the sediment load at a rate of $11,24,41$ and $62 \%$, respectively. These results indicate the importance of correct measurement of particle size in suspension and in bed (Ulke 2010).

\section{Conclusions}

This study shows that Brooks method is the most appropriate empirical model for predicting suspended sediment loads in the major rivers of Aegean Region in Turkey. Its performance can be substantially improved by the genetic algorithm (GA_Brooks method), which can give results compatible with those of ANNs and ANFIS. GA_Brooks, ANNs, and ANFIS models can be used for predicting loads at a regional scale. When using these methods in a regional analysis, extra care should be given to choose basins (or sub basins) which have similar characteristics for a better performance. The standardization (compaction) method can be employed in the regional analysis in order to prevent some stations from becoming dominant over others Brooks method should not be used by itself for predicting suspended sediment loads at a regional scale. The sensitivity analysis results revealed that suspended and bed 
material particle diameters affect suspended sediment loads significantly. Therefore, it will be important to obtain spatial and temporal particle diameter information, if possible. Furthermore, the results have shown that GA performs satisfactorily for different data partitioning.

Acknowledgments The authors would like to thank EIE [General Directorate of Electrical Power Resources Survey and Development Administration] for providing the flow and sediment data and DMI [Turkish State Meteorological Service] for providing the precipitation data. The authors would also like to thank to the Geotechnical and Environmental laboratories of the Dokuz Eylul University for the analysis of the field samples.

\section{References}

Alp M, Cığızoğlu HK (2007) Suspended sediment load estimation by two artificial neural network methods using hydro meteorological data. Environ Model Softw 22:2-13

ASCE (2000) Artificial neural networks in hydrology. I: Preliminary concepts. Journal of Hydrologic Eng. ASCE 5(2): $115-123$

Aytek A, Kisi O (2008) A genetic programming approach to suspended sediment modelling. J Hydrol 351:288-298

Camenen B, Larson M (2008) A general formula for noncohesive suspended sediment transport. J Coast Res 24(3):615627

Chaudhry MH (1993) Open-channel flow. Prentice Hall, Englewood Cliffs, p 523

Cybenco G (1989) Approximation by superposition of a sigmoidal function. Math Control Signals Syst 2:303-314

Dietrich WE (1982) Settling velocity of natural parts. Water Resour Res 18(6):1615-1626

DMI (2010) Turkish state meteorological service, www.meteor.gov.tr

DSI (2010) General directorate of state hydraulic works, www.dsi.gov.tr

EIE (2006) Suspended sediment data for surface waters in Turkey. General Directorate of Electrical Power Resources Survey and Development Administration, Ankara

EIE (2010) General directorate of electrical power resources survey and development administration, www.eie.gov.tr

Girma NT, Horlacher HB (2004) Investigation of performance of sediment transport formulas in natural rivers based on measured data in Kulfo River, Southern Ethiopia. FWU, Vol. 4, Lake Abaya Research Symposium, Proceedings

Goldberg DE (1989) Genetic algorithms for search, optimization, and machine learning. Addison-Wesley, USA Goldberg DE (1999) Genetic Algorithms. Addison-Wesley, USA

Graf WH (1984) Hydraulics of sediment transport. Water Resources Publications, Colorado, p 513

Gray J, Fisk G (1992) Monitoring radionuclide and suspended sediment transport in the Little Colorado Rover Basin, Arizona and New Mexico, USA. Proceedings of the Symposium Erosion and Sediment Transport Monitoring Programmes in River Basins. Oslo, IAHS publ. No. 210:505-516

Guan J, Aral MM (2005) Remediation system design with multiple uncertain parameters using fuzzy sets and genetic algorithm. J Hydrol Eng 10(5):386-394

Guven A, Kisi O (2011) Estimation of suspended sediment yield in natural rivers using machine-coded linear genetic programming. Water Resour Manag 25:691-704

Haykin S (1998) Neural networks - A comprehensive foundation, 2nd edn. Prentice-Hall, Upper Saddle River, pp 26-32

Horowitz AJ (1997) Some thoughts on problems associated with various sampling media used for environmental monitoring. Analyst 122:1193-1200

Jain A, Bhattacharjya RK, Sanaga S (2004) Optimal design of composite channels using genetic algorithm. J Irrig Drain Eng 130(4):286-295

Jang JSR (1993) ANFIS: adaptive-network-based fuzzy inference system. IEEE Trans Syst Man Cybern 23:65-85 Jimanez JA, Madson OS (2003) A simple formula to estimate settling velocity of natural sediments. J Watervay Port, Coastal Ocean Eng 129(2):70-78

Julien PY (2002) River mechanics. Cambridge University Pres, Cambridge, p 434

Kavvas ML, Yoon J, Chen ZQ, Liong L, Dogrul EC, Ohara N, Aksoy H, Anderson ML, Reuter J, Hackley S (2006) Watershed environmental hydrology model: environmental module and its application to a California watershed. J Hydrol Eng ASCE 11(3):261-272

Kisi O (2012) Modeling discharge-suspended sediment relationship using least square support vector machine. J Hydrol 456-457:110-120

Kisi O, Shiri J (2012) River suspended sediment estimation by climatic variables implication: Comparative study among soft computing techniques. Comput Geosci 43:73-82

Kisi O, Yuksel I, Dogan E (2008) Modelling daily suspended sediment of rivers in Turkey using several datadriven techniques. Hydrol Sci J 53(6):1270-1285 
Kisi O, Dailr AH, Çimen M, Shiri J (2012) Suspended sediment modeling using genetic programming and soft computing techniques. J Hydrol 450-451:48-58

Ladewig MD (2006) Sediment transport rates in the Lower Muskegon River and Tributaries. MSc Thesis. University of Michigan, Natural Resources and Environment, USA

Lafdani EK, Nia AM, Ahmadi A (2013) Daily suspended sediment load prediction using artificial neural networks and support vector machines. J Hydrol 478:50-62

Lee G-S, Lee K-H (2010) Determining the sediment delivery ratio using a sediment-rating curve and a geographic information system — embedded soil erosion model on a basin scale. J Hydrol Eng ASCE 15(10):834-843

Liong SY, Chan WT, Shreeram J (1995) Peak flow forecasting with genetic algorithm and SWMM. J Hydraul Eng ASCE 121(8):613-617

Nagy HM, Watanabe K, Hirano M (2002) Prediction of sediment load concentration in rivers using artificial neural network model. J Hydraul Eng 128(6):588-595

Nourani V, Andalib G (2015) Daily and monthly suspended load predictions using wavelet based artificial intelligence approaches. J Mt Sci 12(1):85-100

Nourani V, Alizadeh F, Roushangar K (2016) Evaluation of a two-stage SVM and spatial statistics methods for modeling monthly river suspended sediment load. Water Resour Manag 30:393-407

Olive LJ, Rieger WA (1988) On examination of the role of sampling strategies in the study of the suspended sediment transport. Sediment Budgets, Proceedings of the Porto alegre Symposium, IAHS Publ., No. 174:259-267

Ozturk F, Apaydın H, Walling DE (2001) Suspended sediment loads through flood events for streams of Sakarya River Basin. Turk J Eng Environ Sci 25:643-650

Partal T, Cigizoglu HK (2008) Estimation and forecasting of daily suspended sediment data using wavelet-neural networks. J Hydrol 358:317-331

Picouet C, Hingray B, Olivry JC (2001) Empirical and Conceptual modeling of the suspended sediment dynamics in a large tropical African river: The upper Niger River basin. J Hydrol 250:19-39

Rajaee T (2011) Wavelet and ANN combinatiom model for prediction of daily suspended sediment load in rivers. Sci Total Environ 409:2917-2928

Rojas R, Velleux M, Julien PY, Johnson BE (2008) Grid scale effects on watershed soil erosion models. J Hydrol Eng ASCE 13(9):793-802

Sen Z (2004) Genetic algorithm and optimization methods. Su Vakfi Yayinlari, Istanbul. (Turkish), ISBN: 975-6455-12-8

Sen Z, Oztopal A (2001) Genetic algorithms for the classification and prediction of precipitation occurrence. Hydrol Sci J 46(2):255-267

Simons DB, Senturk F (1992) Sediment transport technology, water and sediment dynamics. Water Resources Publications, Colorado, p 897

Singh RM, Datta B (2006) Identification of groundwater pollution sources using GA-based linked simulation optimization model. J Hydrol Eng ASCE 11(2):101-109

Singh VP, Tayfur G (2008) Kinematic wave theory for transient bed sediment waves in alluvial rivers. J Hydrol Eng ASCE 13(5):297-304

Singh VP, Woolhiser DA (2002) Mathematical modeling of watershed hydrology. J Hydrol Eng ASCE 7(4):270-292

Tayfur G (2003) Modelling sediment transport. In: Singh VP, Yadava RN (eds) Watershed Hydrology. Allied Publishers, p 353-375

Tayfur G (2009) GA-optimized model predicts dispersion coefficient in natural channels. Hydrol Res 40(1):65-78

Tayfur G (2012) Soft computing in water resources engineering; artificial neural networks, fuzzy logic and genetic algorithm. WIT Press, Southampton, p 267

Tayfur G, Guldal V (2006) Artificial Neural Networks for estimating daily total suspended sediment in natural streams. Nord Hydrol 37(1):69-79

Tayfur G, Moramarco T (2008) Predicting hourly-based flow discharge hydrographs from level data using genetic algorithms. J Hydrol 352(1-2):77-93

Tayfur G, Singh VP (2006) ANN and fuzzy logic models for simulating event-based rainfall-runoff. J Hydraul Eng ASCE 132(12):1321-1330

Tayfur G, Singh VP (2007) Kinematic wave model for transient bed profiles in alluvial channels under nonequilibrium conditions. Water Resour Res 43, W12412

Tayfur G, Singh VP (2011) Predicting mean and bankfull discharge from channel cross-sectional area by expert and regression methods. Water Resour Manag 25(5):1253-1267

Tayfur G, Barbetta S, Moramarco T (2009) Genetic Algorithm-based discharge estimation at sites receiving lateral inflows. J Hydrol Eng ASCE 14(5):463-474

Ulke A (2010) Application of empirical, regression and artificial intelligence methods for the sediment transport in natural streams of the aegean region. PhD Thesis (in Turkish), Dokuz Eylul University, The Graduate School of Natural and Applied Science, Izmir

Ulke A, Tayfur G, Ozkul S (2009) Predicting suspended sediment loads and missing data for Gediz River, Turkey. J Hydrol Eng ASCE 14(9):954-965 
Ulke A, Ozkul S, Tayfur G (2011) Empirical methods for predicting suspended sediment load in Gediz River. IMO Teknik Dergi 22(2):5387-5407

Woitke P, Wellmitz J, Helm D, Kube P, Lepom P, Litheraty P (2003) Analysis and assessment of heavy metal pollution in suspended solids and sediments of the river Danube. Chemosphere 51:633-642

Wu W (2004) Depth-averaged two-dimensional numerical modeling of unsteady flow and nonuniform sediment transport in open channels. J Hydraul Eng ASCE 130(10):1013-1024

Wu W, Vierira DA, Wang SSY (2004) One-dimensional numerical model for nonuniform sediment transport under unsteady flows in channel networks. J Hydraul Eng ASCE 130(9):914-923

Yang CT (1996) Sediment transport theory and practice. McGraw-Hill, USA, p 897

Yang CT, Molinas A, Wu B (1996) Sediment transport in the Yellow River. J Hydraul Eng ASCE 122(5):237-244

Yang CT, Marsooli R, Aalami T (2009) Evaluation of total sediment transport formulas using ANN. Int J Sediment Res 24:274-286 